\title{
A Study of Teaching Aptitude of Science Teachers of Senior Secondary Schools
}

\author{
Dr. Mahesh Kumar Muchhal ${ }^{1 *}$, Arun $\operatorname{Kumar}^{2}$
}

Keywords: Teaching Aptitude, Science Teachers, Senior Secondary Schools

"The destiny of India is being shaped in her classroom" has been pointed out by the education Commission (1964-66), and to that point it may be safely added that the destiny of these classrooms is being shaped by the teachers. Teacher is a flywheel of the whole educational machine. Modern school plans the best equipments, the newest of the new media and the most progressive methods; they will remain dead fossils unless there is the right use of teacher's breath, life and spirit into them. Hence, the teacher occupies a pivotal position in all schemes of educational reconstruction.

A teacher is the embodiment of honesty, courage justice, nobility and wisdom and above all he is a Karamayogi who believes in purity of thought and action. The document "challenge of education - a policy perspective (1985)" has highlighted teacher's performance in the most crucial input in the field of education. No development of new technology can revolutionize the classroom teaching unless capable and committed teachers are in teaching profession. The success of a teacher depends on his self-control, good teaching aptitude and work - oriented mind. So, the well adjustment of a teacher is necessary for good results in education. Therefore, here an attempt has been made to study the teaching aptitude of science teacher of senior secondary schools.

The word 'aptitude' is derived from the word 'aptos' which means fitness for. It is often used interchangeably with the term 'ability'. Ability refers to a general trait of an individual that may facilitate in the learning of a variety of specific skills. But aptitude is different from ability as given under:

\footnotetext{
${ }^{1}$ Associate Professor, Digamber Jain (PG) College Baraut, Baghpat (U.P)

${ }^{2}$ Assistant Teacher, P.S Belda Bujurg, Deoband Saharnapur

*Responding Author

(C) 2016 I M Muchhal, A Kumar; licensee IJIP. This is an Open Access Research distributed under the terms of the Creative Commons Attribution License (http://creativecommons.org/licenses/by/2.0), which permits unrestricted use, distribution, and reproduction in any Medium, provided the original work is properly cited.
} 
Ability is concerned with present. It indicates the combination of skills, habits and powers which an individual now has and which enables him to do something. Aptitude looks to the future and, on the basis of the habits, skills and abilities that an individual now has, predicts what he, with training, may become and what success he may have in a given occupation or position. Aptitude refers to mental capacity, native or acquired. It is the part of a person's mental equipment. Which gives him a special fitness for any kind of Endeavour? Such an aptitude may be the result of either an innate endowment or of special training or both.

The term 'ability' is often used interchangeably with the term 'aptitude'. The results showed that women came in training from all classes of families. On the other hand, men were drawn largely from the families engaged in somewhat inferior profession. The study revealed that children of teacher did not necessarily join teaching profession. As far as the academic achievement is concerned, the investigation showed that men having poor performance in graduation join teaching whereas women with better divisions in graduation joined this profession. The reasons may be that they regard it as an easy and soft profession having long holidays. Some became teachers accidentally for finding living or under other compulsive circumstances.

In many spheres in everyday life, we usually come across the individuals who under similar circumstances excel the others in acquiring certain knowledge or skills and prove themselves more suitable and efficient in certain specific abilities. Individuals having the same level of intelligence may not show the same results if they are put to the same work. Something other than intelligence, other things being equal, which enables an individual to learn the task more successfully may be characterized as aptitude.

\section{REVIEW RELATED TO LITERATURE}

Dass (1951), of Nagpur University conducted his study on university training college in Nagpur on three hundred pupil teachers; he investigated into the family profession ability as expressed by academic achievement subject to the study.

Sharma (1984), conducted a study on 'Teaching Aptitude, Intellectual Level and Morality of Prospective Teachers' About $75 \%$ of students were below average in teaching aptitude and intellectual level;

i) An insignificant difference was found in teaching aptitude, ability in sex wise and discipline wise comparison.

ii) A positive correlation was found between teaching aptitude, intellectual level, and morality.

Lalithamna (1986), has investigated an enquiry into classroom instruction. The major objectives of the study were:

i) To identify and list of teaching skill required for effective classroom instruction;

ii) To compare instructional material for developing some of the identified teaching skills. He found some major skills which are required for effective class room 


\section{A Study of Teaching Aptitude of Science Teachers of Senior Secondary Schools \\ teaching as under: skills of planning, skills of identifying learner's entry behaviour, skill of writing instructional objectives.}

More (1988), examined the relationship between teaching effectiveness, teaching aptitude and personality traits: The objective of the study was to bring an improvement in the criteria for admission in the teachers preparation programme (B.Ed. training for secondary teachers).

The study by Kohalon and Saini (1989), was concerned with the impact of teacher education on the teaching aptitude of education graduates of Punjab Agriculture University. The relationship between academic achievement and teaching aptitude was also investigated. All the 20 students of B.Ed. programme of Punjab Agricultural University participated in the study. Teaching aptitude was measured in terms of various personality traits. The researchers found that teacher education helps to develop teaching aptitude $(\mathrm{t}=2.23 ; \mathrm{p}=0.05)$ and the academic achievement has low positive correlation ( $\mathrm{r}=0.21)$ with teaching aptitude.

Srivastava (1990), in his evaluation of the impact of training found that it did improve teaching efficiency which in terms influenced the attitude and aptitude of the student-teachers.

Chandrakanta Pal (2000), submitted a M.Phil. dissertation in K.U. Kurukshetra. He conducted a study of teaching aptitude of primary school teachers and their teaching competency. The main findings of the study were:

1. Knowledge of subject matter, faith in co-operative and democratic ways of teaching were positively correlated to flexibility teaching aptitude, planning, presentation, evaluation and teaching competency.

2. Emotional and social adjustments were positively correlated to managerial trait.

3. Teaching aptitude was positively correlated to planning, presentation, closing, evaluation, managerial and teaching competency.

4. These existed significant difference between higher and lower teaching competency teacher groups towards teaching aptitude. Teacher with high teaching competency show high teaching aptitude.

5. No significant difference was found between the higher and lower teaching competency groups towards emotional and social adjustment.

6. There was no significant difference in teacher's teaching aptitude, whether they had high or low teaching experience.

\section{OBJECTIVES}

a) To study the teaching aptitude of science teachers of senior secondary schools.

b) To study the difference between teaching aptitude of government and private science teachers of senior secondary schools.

c) To study the difference between teaching aptitude of male and female science teachers of senior secondary schools. 


\section{Hypotheses}

1. There exists no significant difference between teaching aptitude of male and female science teachers.

2. There exists no significant difference between teaching aptitude of government and private science teachers of senior secondary schools.

\section{Sample}

In the present study, 30 science teachers of 15 senior secondary schools were selected as a sample from the population through the convenient sampling method. The sample consisted of 15 male and 15 female science teachers and 15 government and 15 private schools science teachers. The sample is given in the following table:

\section{Table No.1}

\begin{tabular}{|c|c|c|c|c|}
\hline $\begin{array}{l}\text { S. } \\
\text { No. }\end{array}$ & School & Male & Female & Total \\
\hline a) & \multicolumn{4}{|l|}{ PRIVATE } \\
\hline 1. & K.K. Public School, Sardhana, Meerut & 2 & - & 2 \\
\hline 2. & Diwan Public School, Meerut Cantt. & 1 & 1 & 2 \\
\hline 3. & Vardhman Senior Secondary Academy, Meerut & 1 & 1 & 2 \\
\hline 4. & Meerut Girls Public School, Sastri Nagar, Meerut & - & 2 & 2 \\
\hline 5. & Dayawati Modi Academy, Modipuram, Meerut & 1 & 1 & 2 \\
\hline 6. & D.P.M. Public School, Bahsooma, Meerut & 2 & - & 2 \\
\hline 7. & Bal Bharti Public School, Mawana, Meerut & 1 & 1 & 2 \\
\hline \multirow[t]{2}{*}{8.} & Karan Public Schhol, Pandav Nagar, Meerut & - & 1 & 1 \\
\hline & Total Private Teachers & 8 & 7 & 15 \\
\hline b) & \multicolumn{4}{|l|}{ GOVERNMENT } \\
\hline 1. & Kisan Inter College, Mohiuddinpur, Meerut & 2 & - & 2 \\
\hline 2. & Gandhi Vidya Peeth Inter College, Dabathua, Meerut & 1 & 1 & 2 \\
\hline 3. & Arya Kanya Inter College, Meerut & - & 2 & 2 \\
\hline 4. & Navbharat Vidya Peeth Inter College, Partapur, Meerut & 1 & 1 & 2 \\
\hline 5. & Johra Memorial Inter College, Kashi, Meerut & 1 & 1 & 2 \\
\hline 6. & Dr. Ambedkar Inter College, Tej Garhi, Meerut & 1 & 1 & 2 \\
\hline \multirow[t]{3}{*}{7.} & Government Inter College, Hastinapur, Meerut & 1 & 2 & 3 \\
\hline & Total Government Teachers & 7 & 8 & 15 \\
\hline & Total Government \& Private Teachers & 15 & 15 & 30 \\
\hline
\end{tabular}

\section{Tool Used}

Teacher's Teaching Aptitude Questionnaire by Dr. R.P. Srivastava and Dr. (Smt.) Geeta Tiwari (1986) was used. 


\section{RESULTS}

Table No. 2, Difference Between Teaching Aptitude of Private and Government School Science Teachers

\begin{tabular}{|l|l|l|l|l|l|l|}
\hline Group & N & Mean & S.D. & S.E.M. & 't' ratio & $\begin{array}{l}\text { Level of } \\
\text { Sig. }\end{array}$ \\
\hline Govt. & 15 & 353.63 & 5.44 & 2.059 & 0.515 & Not Sig. \\
\hline Private & 15 & 352.57 & 5.83 & & \\
\hline
\end{tabular}

\section{INTERPRETATION}

The above table 4.1 shows that there is no significant difference between teaching aptitude of the private and government teachers. Mean and Standard Deviation of the 15 government science teachers are 353.63 and 5.44 respectively. Mean and standard deviation of the 15 private science teachers are 352.57 and 5.83 respectively. Standard error between means is 2.059. The't' ratio between the mean scores comes out to be 0.515 , which is less than the table value at both the levels of significance, i.e. at 0.05 and 0.01 levels. So,'t' ratio is not significant at both levels. Therefore, null hypothesis (Ho) is accepted. It shows that there is no significant difference between teaching aptitude of government and private senior secondary school science teachers.

Table No. 3, Difference between Teaching Aptitude of the Male and Female Science Teachers

\begin{tabular}{|l|l|l|l|l|l|l|}
\hline Group & N & Mean & S.D. & S.E.M. & 't' ratio & $\begin{array}{l}\text { Level of } \\
\text { Sig. }\end{array}$ \\
\hline Male & 15 & 352.57 & 5.37 & \multirow{2}{*}{1.92} & 0.552 & Not Sig. \\
\cline { 1 - 5 } Female & 15 & 353.63 & 5.18 & & & \\
\hline
\end{tabular}

\section{INTERPRETATION}

The above table 4.2 shows that there is no significant difference between teaching aptitude of the male and female science teachers. Mean and Standard Deviation of the 15 male science teacher are 352.57 and 5.37 respectively and of 15 female science teachers are 353.63 and 5.18 respectively. Standard error between means is 1.92 . The ' $t$ ' ratio between the mean is 0.552 , which is less than both the significant levels. So, 't' ratio is not significant at both 0.05 and 0.01 levels. Therefore, null hypothesis (Ho) is accepted. It shows that there is no significant difference between teaching aptitude of male and female science teachers.

\section{FINDINGS}

1. There existed no significant difference between teaching aptitude of government and private senior secondary school science teachers. It stated that all government and private senior secondary school science teachers had the same capacity of teaching aptitude. 
2. There existed no significant difference between teaching aptitude of male and female senior secondary school science teachers. It stated that all male and female science teachers of senior secondary had the same capacity of teaching aptitude.

\section{REFERENCES}

Adaval, S.B., Qualities of Teacher, Amitab Publishers, Bank Road, Allahabad, (1979).

Adaval, S.B., The Third India Year Book of Educational Research, N.C.E.R.T., Delhi, 1968, pp. 317.

Aggarwal, Y.P., Statistical Methods, Concept, Applications and Computation, Sterling Publishers, New Delhi, 1988.

Bhattacharya, S. Foundation of Education \& Educational Research, Acharya Book Depot, Baroda, 1968, pp. 384.

Bingham, W.V.D., Aptitude and Attitude Testing, Harper and Brothers, 1937, pp. 21.

Buch, M.B., Fifth Survey of Research in Education (1988-92), N.C.E.R.T., New Delhi, 1992.

Buch, M.B., Fourth Survey of Research in Education (1983-88), N.C.E.R.T., New Delhi, 1992.

Buch, M.B., Third Survey of Research in Education (1978-83), N.C.E.R.T., New Delhi, 1987.

Chauhan, S.S., Advanced Educational Psychology, Vikash Publishing House, New Delhi, 1992.

Dass, R.C., The Influence of Family Profession, Nagpur University, Nagpur, 1951.

Dattarya, G. Samant, The Making of Educational Research, Popular Prakashan, Bombay, 1966, pp. 93.

Dewey, B.B., Relationship Between Pupil's Characteristics and Classroom Behaviour of Teacher, Ph.D. Edu, Gorakhpur University, Gorakhpur, 1979, pp. 96.

Dewey, John, Dictionary of Education, Philosophical Library, New York.

Freeman, F.S., Theory and Practice of Psychological Testing, Oxford and I.B.H., Bombay, 1971, pp. 43.

Gates, A.S. \& A.T. Jersild, Education Psychology, Memilling \& Company, New York, 1970, pp. 614-615.

Good, C.V., Introduction to Educational Research, Appleton Century Crafth, New York, 1963, p.p. 542.

Good. C.V., Dictionary of Education, Mc Graw Hill book Co., New York, 1959.

Guelford, J.P., Fundamental Statistics in Education and Psychology, McGraw Hill Book Co., 1956, pp. 261.

Jain R., Proficiency in Teaching as a Function of Creativity, Intelligence and Interest, Ph.D. Edu, Meerut University, Meerut, 1988.

Kapil, H.K., Research Methods in Behavioural Science, H.P. Bhargava book House, Agra, 2004.

Kaul, Lokesh, Methodology of Educational Research, Vikash Publishing House, New Delhi, 1984.

Kundu, C.L., Indian Year Book of Teacher Education, Sterling Publishers, New Delhi, 1988.

Mangal, S.K., Psychological Foundation of Education, Prakash Brothers, New Delhi, 1972.

Mitra, R., Some Determinants of Academic Performance in Preadolescent children, Ph.D. Edu., Calcutta University Calcutta, 1985. 
Sharma, R.A. Parametric \& Non Parametric Statistics, Surya Publication, Meerut, 1996.

Sharma, R.A., Essentials of Scientific Behavioural \& Research, R. Lall Book Deptot, Meerut, 2000.

Sharma, R.A., Measurement and Evaluation, Loyal Book Depot, Meerut, 1993.

Sharma, R.C., Teaching Aptitude Intellectual Level and Morality of Prospective Teachers, Ph.d. Edu., M. Sukhadia University, Gujrat, 1984.

Shrivastava, D.N., Methodology of Educational Research, Vinod Pustak Mandir, Agra, 1998.

Singh, L.C., Teacher Education in India, N.C.E.R.T., New Delhi, 1990.

Verma, M., An Introduction of Educational and psychological Research, Asia Publishing House, New Delhi, 1965.

Wal, J.C., Essential of Education Psychology, Vikash Publishing House, New Delhi, 2000. 